\title{
Havayolları İç Hatlarda Algılanan Hizmet Kalitesinin Müşteri Memnuniyeti ve Tekrar Satın Alma Davranışına Etkisi
}

\author{
Halil Korkmaz ${ }^{a^{*}}$, İbrahim Giritlioğlu ${ }^{b}$, Cevdet Avcıkurtc \\ aÇanakkale Onsekiz Mart Üniversitesi, Turizm Fakültesi, Çanakkale. \\ ${ }^{b}$ Gaziantep Üniversitesi, Turizm İşletmeciliği Yüksekokulu, Gaziantep. \\ cBalıkesir Üniversitesi, Turizm Fakültesi, Balıkesir.
}

\begin{abstract}
Öz
Yapılan bu araştırmanın amacın Türkiye'de havayollarında algılanan hizmet kalitesinin boyutlarmın ortaya konularak, Türkiye'de iç hatlarda seyahat eden yolcularm havayollarmda algılanan hizmet kalitesinin müşteri memnuniyeti ve müşterilerin tekrar satın alma davranışına olan etkisinin incelenmesi oluşturmaktadır. Bu amacın gerçekleştirilebilmesi için oluşturulan anket formu, İzmir Adnan Menderes havaalanından seyahat eden ve farklı havayollarnı kullanan 311 yolcu üzerinde gerçekleştirilmiştir. Yapılan araştırmanın sonucunda havayollarında alg̨lanan hizmet kalitesinin beş boyuta sahip olduğu sonucu tespit edilirken, müşterilerin havayollarında algılanan hizmet kalitesinin, müşteri memnuniyetine ve müşterilerin tekrar satın alma davranışına önemli etkilerinin olduğu sonucu ortaya konulmuştur.
\end{abstract}

Anahtar Kelimeler: Havayolu, Hizmet Kalitesi, Müşteri Memnuniyeti, Tekrar Satın Alma Davranışı, Türkiye.

\section{The Effect of Perceived Service Quality, Customer Satisfaction and Repeat Purchase Behavior in Domestic Airlines}

\begin{abstract}
The purpose of this study is to find out the dimensions of passengers' perceived service quality in domestic routes of Turkey and to put forth the effect of airlines perceived service quality to customer satisfaction and repeat purchasing behavior of passengers. For this purpose, a survey conducted over 311 passengers who were using different airlines in Izmir Adnan Menderes airport. As the result of the study, five dimensions of perceived airline service quality were found. Also, there was significant effect of perceived airline service quality on customer satisfaction and repeat purchasing behavior of customers were found.
\end{abstract}

Key words: Airline, Service Quality, Customer Satisfaction, Repeat Purchasing Behaviour, Turkiye.

\section{Gíriş}

Turizm sektörü son yıllarda ekonomik etkinliğini önemli düzeyde arttırmıştır. Turizm sektörünün sağladığı ekonomik gelişim, gelişmiş ülkelerde olduğu kadar gelişmekte olan ülkelerin ekonomisi açısından da büyük önem arz etmektedir (Dwyer vd., 2004; Oh vd., 2007). Turizm sektörünün gelişiminde ulaştırma işletmeleri hayati bir fonksiyona sahiptir (Mahajan ve Rau, 2009). Ulaştırma hizmetleri ve bu hizmetlerin bir destinasyondaki gelişmişlik düzeyi destinasyona daha fazla ziyaretçi gelmesi ve destinasyonların turizmden elde ettikleri gelirleri arttırmasında son derece önemlidir (Global Report on Aviation, 2012). 
Turizm sektöründe ulaştırma işletmelerinin en önemli payını havayolu işletmeleri oluşturmaktadır. Dünya Turizm Örgütü'nün raporuna göre 2013 yılında toplam turistik faaliyetlerin yüzde 53'ü havayolu işletmeleri ile gerçekleştirilmiştir (WTO, 2014: 4). Öte yandan turizm sektöründe destinasyonların seçimine olan etkisi, tatil için zaman tasarrufu sağlaması, diğer ulaşım araçlarına göre çoğu zaman daha ekonomik ve güvenilir olması gibi unsurlar havayolu işletmelerinin diğer işletmelere oranla avantajinı ortaya koymaktadır (Frost ve Kumar, 2001; Chen, 2008). Havayolu sektörü, bu sektöre son yıllarda yeni firmaların katılmasıyla daha rekabetçi bir yapıya sahip olmuş ve bu sektörde ayakta kalabilmek için müşterilere kaliteli hizmet sunma zorunluluğu ortaya çıkmıştır (Tsaur vd., 2002; Chen ve Chang, 2005). Müşterilere kaliteli hizmet sunma durumu ise onların beklentilerine uygun ürün ve hizmetlerin sunulmasıyla gerçekleşmektedir. Müşterilere kaliteli hizmet sunan işletmeler, müşteri memnuniyetini sağlayarak daha fazla sadık müşteri elde edilebilmektedir (Nadiri vd., 2008). Yapılan araştırmalar sadık müşterileri elde tutmanın yeni müşteriler kazanmaktan daha karlı bir eylem olduğuna vurgu yapmaktadır (Park vd., 2004; Saha ve Theingi, 2009).Yapılan bu araştırmanın amacını Türkiye'de havayollarında algılanan hizmet kalitesinin yapısının tespit edilerek; Türkiye'de havayollarında algılanan hizmet kalitesinin müşteri memnuniyeti ve müşterilerin tekrar satın alma davranışına olan etkilerinin ortaya konulması oluşturmaktadır. Bu amaçtan yola çıkarak ilgili araştırma kapsamında cevap aranacak sorular ise şunlardır:

- Havayollarında hizmet kalitesi kaç boyuttan oluşmaktadır?

- Havayollarında algılanan hizmet kalitesi, müşterilerin o işletmeden tekrar satın alma davranışını pozitif yönde etkilemekte midir?

- Havayollarında algilanan hizmet kalitesi müşteri memnuniyetini pozitif yönde etkilemekte midir?

- Havayollarında yolcu memnuniyeti, algılanan hizmet kalitesi ile birlikte tekrar satın alma davranışını pozitif yönde etkilemekte midir?

- Havayollarında yolcu memnuniyeti, algılanan havayolu hizmet kalitesi ve tekrar satın alma niyeti arasında kısmi aracılık etkisi yapmakta mıdır?

\section{LITERATÜR}

Havayolu sektörü ve bu sektörün sunduğu hizmetler turizm sektörü açısından son derece önemlidir. Yapılan araştırmalar bir destinasyonun, destinasyon imajını arttırması ve o destinasyona daha fazla turist çekilmesinde havayolu hizmetlerinin öncelikli etkisinin olduğunu ortaya koymaktadır. Bir destinasyona yönelik havayolu hizmetlerinin zenginliği ve çeşitliliği, o destinasyonun markasını geliştirmesi ve marka bilinilirliğini arttırması ile doğrudan ilişkilidir (Hui, 2003; Global Report on Aviation, 2012).

Havayolu sektörünü oluşturan işletmeler, diğer işletmelerde olduğu gibi hizmet sunduğu müşterilere kaliteli hizmet sunmak durumundadır (Suzuki vd., 2001; Robledo, 2001). Günümüz yıkıcı rekabet ortamında yalnızca müşterilerine kaliteli mal ve hizmet sunan işletmeler faaliyetlerini devam ettirmeyi başarabilmektedir. Havayolu 
hizmetlerinin hizmetin genel özelliklerinden olan soyut olması, üretildiği yerde tüketilme zorunluluğu, türdeş olmaması ve stoklanma özelliğinin bulunmaması gibi durumlar havayollarında hizmet kalitesi kavramının kavramsallaştırılması ve hizmet kalitesinin ölçülmesini zorlaştırmaktadır (Chang ve Yeh, 2002; Giritlioğlu, 2012; Kalthom, 2012). İlgili yazında havayollarında hizmet kalitesinin kavramsallaştırılması üzerine çeşitli araştırmalar gerçekleştirilmiş ve yapılan araştırmalar sonucunda havayollarında algılanan hizmet kalitesinin birbirinden farklı boyutlara sahip olduğu ortaya konulmuştur (Okumuş ve Asil, 2007; Park, 2007; Çelikkol vd., 2012; Pekkaya ve Akıllı, 2013;). Yapılan bazı araştırmalar hizmet kalitesinin iki boyuta sahip olduğunu ortaya koyarken (Chen ve Chang, 2005; Çelikkol vd., 2012), bazı araştırmalar beş (Chang ve Yeh, 2002; Okumuş ve Asil, 2007; Kalthom vd., 2012; Pekkaya ve Akıllı, 2013), bazı araştırmalar altı (Park, 2007; Lu ve Ling, 2008) ve bazı araştırmalar ise havayollarında algılanan hizmet kalitesinin yedi boyuta sahip olduğunu ortaya koymuşlardır (Gilbert ve Wang, 2003; Okumuş ve Asil, 2007). İlgili araştırmaların sonuçlarından görüldügü üzere havayollarında hizmet kalitesinin gerçekte kaç boyuta ve kaç farklı özelliğe sahip olduğu henüz net bir şekilde ortaya konulamadığı gibi; havayollarında hizmet kalitesi boyutunun müşterilerin kültürüne ve havayolu işletmelerinin türüne göre farklılık gösterdiği ilgili çalışmalarda özellikle vurgulanmaktadır. Havayollarında hizmet kalitesinin ölçülmesi üzerine yapılan araştırmalarda kalitenin ölçülmesinde hangi ölçeğin kullanılmasının uygun olabileceği, araştırmacılar tarafından göz önüne alınan diğer bir konu olmuştur. Yapılan bazı araştırmalar havayollarında algılanan hizmet kalitesinin ölçülmesinde SERVQUAL modelini kullanırken (Okumuş ve Asil, 2007; Ataman vd., 2011; Yıldız ve Erdil, 2013), bazı araştırmacılar ise SERVPEFR ölçeğini kullanmışlardır (Kalthom vd., 2012; Pekkaya ve Akıllı, 2013; Yıldız ve Erdil, 2013). Öte yandan bazı araştırmacılar havayollarının kendilerine ait bazı hizmet özellikleri olduğunu vurgulayarak sadece bu sektöre yönelik kendi geliştirdikleri ölçekleri araştırmalarında kullanmışlardır (Frost ve Kumar, 2001; Robledo; 2001; Gilbert ve Wong, 2003; Mahajan ve Rao, 2009).

Havayolu işletmelerinde müşterilere sunulan hizmetlerin kalite düzeyi o müşterilerin işletmeden aldığ 1 memnuniyeti önemli ölçüde etkilemektedir (Park vd., 2004; Çelikkol vd., 2012). Sunulan hizmetlerden memnun bir müşteri ise o işletmeden tekrar satın alma ve işletmeyi başkalarına tavsiye etme davranışı gibi olumlu bazı eğilimlere sahip olmaktadır (Park vd., 2004; Nadiri vd., 2008; Chen, 2008; Saha ve Theingi, 2009). Müşterilerin sahip olduğu bu eğilimlerin sayısının havayolu işletmeleri açısından artması ise havayollarının marka değeri ve karlılıklarını arttırmakta ve bu durum da işletmelerin faaliyetlerini daha karlı bir şekilde ve daha uzun süre devam ettirmesine olanak sağlamaktadır.

İlgili yazında havayollarında hizmet kalitesi üzerine yapılan bazı araştırmalar Tablo 1'de verilmektedir. İlgili tablo incelendiğinde havayollarında hizmet kalitesi üzerine yapılan araştırmaların önemli bir kısmının hizmet kalitesini ölçmeye ve havayollarında hizmet kalitesinin kaç boyuta sahip olduğunu ortaya koymayı amaçladığ1 görülür. Öte yandan kültürlerin havayollarında hizmet kalitesini algılama ve algılanan hizmet kalitesinin ölçülmesinde kültürel farklılıkların ortaya konulması 
araştırmacılar tarafından ortaya konulan diğer önemli bir konu olmuştur. Havayollarında algılanan hizmet kalitesinin müşteri memnuniyeti ve tekrar satın alma eğilimine olan etkilerinin incelenmesi araştırmacılar tarafından odaklanılan diğer bir konudur (Tablo 1). Bu çalışmada havayollarında hizmet kalitesinin kaç boyuta sahip olduğu ortaya konulacak hem de bu sektörde hizmet kalitesinin müşteri memnuniyeti ve tekrar satın alma davranışına olan etkileri tespit edilecektir.

Tablo 1. İlgili Yazında Havayollarında Hizmet Kalitesi Üzerine Yapılan Araştırmalar ve Bulguları

Okumuş ve Asil (2007) yapmış olduğu araştırmada Türk Hava Yollarında dış hat uçuşuna katılan yerli ve yabancı yolcuların algılanan hizmet kalitesini ölçmeye yönelik bir araştırma gerçekleştirmiştir. 511 yolcu üzerinde gerçekleştirilen araştırmanın sonucunda her iki kesim yolcuların hizmetlerden memnun oldukları sonucu tespit edilmiştir. Hizmet kalitesi boyutları yerli yolcular için 'güvenilir personel', 'doğru ve güvenilir hizmet', 'hizmette isteklilik ve anında hizmet', 'fiziksel unsurlar' ve 'hizmetin kişisel uygunluğu' olmak üzere beş boyutta olduğu; yabancı yolcular için ise 'hizmette isteklilik ve anında hizmet', 'doğru ve güvenilir hizmet', 'müşteriyi tanıma-anlama', 'fiziksel unsurlar', 'güven telkin etme', 'hizmetin kişisel uygunluğu' ve 'inanılırlık' olmak üzere 7 boyutta olduğu tespit edilmiştir.

Pekkaya ve Akıllı (2013) Atatürk havalimanından 8 farklı havayolu hizmetlerini kullanan 410 yolcu üzerinde gerçekleştirdiği araştırmada hizmet kalitesinin 'Güvenilirlik', 'Fiziksel ortam', 'Heveslilik', 'Güvence' ve 'Empati' olmak üzere 5 başlık altında olduğunu ortaya koymuştur. Araştırmanın sonucunda müşterilerin havayollarında sunulan hizmetlerden genelde memnun oldukları sonucu tespit edilmiştir.

Çelikkol vd. (2012) iç hat uçuşlarını kullanan yolcuların havayolu firmalarını tercih nedenleri ve havayollarında sunulan hizmetlerden memnuniyet düzeyini incelemiştir. İstanbul Sabiha Gökçen havaalanını kullanan 280 yolcu üzerinde gerçekleştirilen araştırmada müşterilerin havayollarını seçerken göz önüne aldığı kriterlerin 'güvenilirlik ve iyi hizmet', 'uzmanlık ve esneklik' ve 'avantaj ve uygunluk' olmak üzere üç başlık altında olduğunu ortaya koyarken, havayollarında hizmet kalitesinin 'Güvenlik ve Kalite' ve 'Rahatlık ve Çeşitlilik' olmak üzere iki boyuttan oluştuğu tespit edilmiştir.

Yıldız ve Erdil (2013) yapmış olduğu araştırmada Türkiye'de havayollarını kullanan müşterilerin algılanan hizmet kalitesinin tespit edilmesini amaçlamıştır. İstanbul Sabiha Gökçen ve Atatürk havalimanlarından seyahat eden 1080 yolcu üzerinde gerçekleştirilen araştırmada hizmet kalitesi 'fiziksel boyutlar', 'güvenilirlik', 'yanıt verebilirlik', 'güvence' ve 'empati' olmak üzere beş başlık altında olduğu tespit edilmiş olup müşterilerin sunulan hizmetlerden genel olarak memnun oldukları ortaya konulmuş̧tur.

Ataman vd. (2011) tarafından yapılan araştırmanın amacını Atatürk havalimanından Türk havayollarıyla iş amaçlı seyahat eden yolcuların businessclass sınıfındaki hizmetlerdeki memnuniyet düzeyi ölçülmüştür. İş amaçlı seyahat eden 225 yolcu üzerine gerçekleştirilen araştırmada SERVQUAL modeli kullanılmıştır. Araştırmanın sonucunda müşterilerin bekledikleri hizmetleri alamadıkları sonucu tespit edilirken; müşterilerin beklentileri ile algıları arasındaki farkın oldukça az olduğu ortaya konulmuştur.

Robledo (2001) uluslararası havayollarında en ideal hizmet kalitesi boyutları ve ölçeği elde etmeyi amaçlayan bir araştırma gerçekleştirmiş̧ir. Yapılan araştırmada havayollarına yönelik geliştirilen 6 modelin geçerliliği test edilmiş olup bunlar arasında havayolları için en uygun ölçeğin yazar tarafından geliştirilen SERVPEX modeli olduğu ortaya konulmuştur. Yazar tarafından geliştirilen modele göre SERVPEX modeli 'fiziksel özellikler', 'güvenilirlik' ve 'müşteriyi koruma' boyutu olmak üzere üç boyuttan oluşmaktadır. 
Park vd. (2004) tarafından yapılan araştırmanın amacını havayollarında algılanan hizmet kalitesinin müşterilerin olumlu davranışlarına olan etkisinin ortaya konulması oluşturmaktadır. Son 12 ayda havayollarını kullanan 592 Koreli yolcu üzerinde gerçekleştirilen araştırmanın sonucunda müşteri beklentilerinin müşterilerin hizmet kalitesi algılamasına; müşterilerin hizmet kalitesine yönelik algısının ise müşteri memnuniyetine önemli derecede etki ettiği sonucu tespit edilmiştir.

Lu ve Ling (2008) tarafından yapılan araştırmanın amacını Çin'den Tayvan'a Tayvan'dan ise Çin'e seyahat eden yolcuların havayollarında algılanan hizmet kalitesinin ölçülmesi oluşturmaktadır. Tayvan'dan Çin'e seyahat eden 262 yolcu, Çin'den de Tayvan'a ziyaret eden 142 yolcu üzerinde gerçekleştirilen araştırmanın sonucunda hizmet kalitesi 'Seyahat öncesi operasyon performansı', 'Uçuşa sevk performansı', 'Uçuştaki görevlilerinin yetenekleri', 'Íletişim ve cevap verme kapasitesi', 'Uçak içi hizmet ve servisler' ve 'güvenlik performansı' olmak üzere altı boyutta incelenmiş olup her iki yolcu grubunun hizmet kalitesine yönelik algılarında farklılık olduğu sonucu tespit edilmiştir.

Lorenzoni ve Lewis (2004) tarafından yapılan araştırmanın amacını havayollarında hizmet hataları sonucunda gösterilen telafi davranışlarının müşteri memnuniyetini sağlamasında işgören milliyetinin herhangi bir etkiye sahip olup olmadığının ortaya konulması oluşturur. 37 İngiliz, 39 İtalyan havayolu çalışanıyla yapılan araştırmanın sonucunda çalışanların milliyetinin hizmet hata aşamasında müşteri memnuniyeti sağlamasında farklılık gösterdiği sonucu tespit edilmiştir.

Chen (2008) tarafından yapılan araştırmada havayollarında hizmet kalitesi ve algılanan değerin müşteri memnuniyetine olan etkisi incelenmiştir. Tayvan'daki bir havayolundan seyahat eden 245 yolcu üzerinde gerçekleştirilen araştırmanın sonucunda müşteri beklentilerinin müşteri memnuniyetine düşük düzeyde etkisi olduğu sonucu tespit edilirken, algilanan değerin memnuniyete önemli derecede etkisi olduğu tespit edilmiştir. Öte yandan müşteri beklentilerinin müşteri algılamaları üzerinde güçlü bir etkisi olduğu, bu araştırma kapsamında ortaya konulan diğer bir bulgu olmuştur.

Park (2007) tarafından yapılan araştırmada son 12 ayda uluslararası uçuşa katılan Koreli ve Avustralyalı yolcuların algıladığı hizmet kalitesinin satın alma davranışına olan etkisi incelenmiştir. 592 Koreli, 501 Avustralyalı havayolu müşterisi üzerine yapılan araştırmada hizmet kalitesi 'uçak içi hizmetler', 'rezervasyon hizmetleri', 'havayolu hizmetleri', 'güvenilirlik', 'çalışanların hizmetleri' ve 'uçuş zenginliği' olmak üzere 6 boyutta incelenmiştir. Araştırmanın sonucunda hizmet kalitesinin hem Avusturalyalı hem de Koreli müşteriler açısından havayolundan satın alma davranışını etkilediği sonucu tespit edilmiştir.

Pekkaya ve Akıllı (2013) tarafından yapılan araştırmada Atatürk Hava Limanından sekiz farklı havayolu hizmetlerini kullanan 410 yolcu üzerinde algılanan hizmet kalitesinin ölçülmesi amaçlanmıştır. Hizmet kalitesinin ölçülmesinde hizmet kalitesi 'güvenilirlik', 'fiziksel ortam', 'heveslilik', 'güvence' ve 'empati' olarak beş başlık altında değerlendirilmiş olup müşterilerin sunulan hizmetlerden genel olarak memnun olduğu sonucu tespit edilmiştir.

Kalthom vd. (2012) tarafından yapılan çalışmanın amacını Kuala Lumpur Havaalanını kullanan müşterilerin havayollarında algılanan hizmet kalitesinin ölçülmesi oluşturmaktadır. Kuala Lumpur havaalanını kullanan 500 Malezyalı üzerinde gerçekleştirilen araştırmanın sonucunda havayollarında hizmet kalitesinin 5 boyuta sahip olduğu tespit edilirken, hizmet kalitesinin 'fiziksel unsurlar', 'güvenilirlik' ve 'güvence' boyutlarının müşteri memnuniyetini önemli derecede etkilediği ortaya konulmuştur.

Sultan ve Simpson (2000) tarafından yapılan araştırmanın amacını Amerika ve Avrupalı müşterilerin Amerikan ve Avrupalı havayollarından memnuniyet düzeyinin ortaya konulması oluşturmaktadır. 716 Amerikan, 1078 Avrupalı yolcu üzerinde yapılan araştırmanın sonucunda 
her iki müşteri grubunun memnuniyetinde farklılıklar olduğu sonucu tespit edilmiştir.

Saha ve Theingi (2009) tarafından yapılan araştırmanın amacını Tayland'da 3 farklı havayolu işletmesinin hizmet kalitesinin tespit edilerek, havayollarındaki hizmet kalitesinin müşteri memnuniyeti ve müşterilerin davranışsal eğilimlere olan etkisin ortaya konulması oluşturmaktadır. 3 farklı havayolundan hizmet alan 1212 yolcu üzerinde gerçekleştirilen araştırmanın sonucunda hizmet kalitesi 'fiziksel özellikler', 'havayolu faaliyet zamanları', 'zamanında kalkış', 'uçuş ekibi ve yer hizmetleri' olmak üzere dört boyutta olduğu sonucu ortaya konulurken yolcuların hizmet boyutlarına göre farklı hizmet kalitesi beklentilerine sahip olduğu sonucu tespit edilmiştir.

Suzuki vd. (2001) tarafından yapılan araştırmanın amacını müşteri memnuniyetine etki eden faktörlerin neler olduğun tespit edilmesi oluşturmaktadır. Yapılan araştırmada müşteri memnuniyetini en çok etki eden unsurların 'zamanında kalkış performansı', 'etkin bagaj prosedürleri' ve 'hızlı check-in ve uçağa alma işlemleri' ile 'iyi bir yiyecek-içecek servisi' olduğu tespit edilmiştir.

Tsaur vd. (2002) tarafından yapılan araştırmanın amacını havayollarında algılanan hizmet kalitesinin ortaya konulması oluşturmaktadır. Tayvan'da havayollarından seyahat eden 211 kişi üzerinde gerçekleştirilen araştırmanın sonucunda havayollarında algılanan hizmet kalitesini en üst düzeyde fiziksel özellikler boyutunun etkilediği sonucu tespit edilmiştir.

Chang ve Yeh (2002) tarafından yapılan araştırmanın amacını Tayvan'da iç hat uçuş yapan 4 havayolu işletmesinin algılanan hizmet kalitesinin ölçülmesi oluşturmaktadır. Tayvan'da 4 havayolu firmasında hizmet alan 354 müşteri üzerinde gerçekleştirilen araştırmanın sonucunda havayolu hizmet kalitesi 'uçak içi rahatlık', 'havayolu çalışanları', 'servislerin güvenilirliği', 'servislerin uygunluğu' ve 'normal dışı durumlarda uygulamalar' olmak üzere beş boyuta sahip olduğu tespit edilmiştir. Araştırmanın sonucunda firmaların farklı hizmet kalitelerine sahip olduğu tespit edilmiştir.

Chen ve Chang (2005) tarafından yapılan araştırmanın amacını Tayvan'da havayollarında sunulan hizmeti kalitesinin müşteri, yöneticiler ve çalışanlar tarafından ölçülmesi oluşturmaktadır. Havayollarına yönelik hizmetlerin 'yer hizmetleri' ve 'uçak içi hizmetler' olarak iki farklı boyuta ayrıldığı çalışmada müşterilerin her iki hizmet türünde de beklediği hizmetleri alamadığı sonucu tespit edilmiştir.

Gilbert ve Wong (2003) tarafından yapılan araştırmanın amacını Hong-Kong havaalanı kullanılarak uçuş yapan yolcuların havayolu hizmet kalitesine yönelik beklentilerinin ortaya konulması oluşturmaktadır. Hong-Kong havaalanından seyahat eden 328 yolcu üzerine gerçekleştirilen araştırmada hizmet kalitesinin 'güvenilirlik', 'güvence', 'imkanlar', 'iş görenler', 'uçuş ile ilgili özellikler', 'kişiselleştirme' ve 'isteklilik' olmak üzere 7 boyuttan oluştuğu tespit edilirken araştırmanın sonucunda müşterilerin seyahat amacı ve etnik yapısına göre havayolu hizmetlerine yönelik farklı beklentilere sahip olduğu görülmüştür.

Mahajan ve Rau (2009) tarafından yapılan araştırmanın amacını Hindistan'da iç hatlarda faaliyet gösteren havayollarında algılanan hizmet kalitesinin ölçülmesi oluşturur. Hindistan'da faaliyet gösteren 4 havayolu işletmesinden hizmet alan 134 müşteri üzerine gerçekleştirilen araştırmanın sonucunda 14 hizmet kalitesi önermesi belirlenmiş olup dört işletmenin de müşterilere hizmetleri farklı kalitelerde sunduğu tespit edilmiştir.

Nadiri vd. (2008) tarafından yapılan araştırmanın amacını havayollarında algılanan hizmet kalitesi boyutlarını belirleyerek hizmet kalitesinin müşteri memnuniyetine olan etkisinin ortaya konulması oluşturmaktadır. Kuzey Kıbrıs'ta ulusal havayolunu kullanan 583 kişi üzerinde yapılan araştırma sonucunda havayoluna yönelik hizmet kalitesinin sekiz boyuta sahip olduğu ortaya konulmuş olup, havayolunda hizmet kalitesinin müşteri memnuniyetine önemli etkisi olduğu sonucu tespit edilmiştir. 
Frost ve Kumar (2001) tarafından yapılan araştırmanın amacını Avustralya' da bir havayolunda ön ve arka planda çalışan personelin havayolunda sunulan hizmet kalitesini değerlendirmesi oluşturmaktadır. Havayolunda görev yapan 366 ön ve 238 arka bölümde çalışan personel üzerinde yapılan araştırma sonucunda INTSERVQUAL adı verilen yeni bir ölçek geliştirilmiş ve hizmet kalitesinin 5 boyuta sahip olduğu ortaya konulmuştur. Öte yandan her iki grupta hizmet yapan işgörenlerin sunulan hizmete yönelik kalite algılarının farklılık gösterdiği sonucu tespit edilmiştir.

İlgili literatüre dayanarak araştırmada belirlenen hipotezleri şu şekildedir:

$\mathbf{H}_{1}$ : Algılanan havayolu hizmet kalitesi, tekrar satın alma niyetini pozitif yönde anlamlı bir şekilde etkilemektedir.

$\mathbf{H}_{2}$ : Alg1lanan havayolu hizmet kalitesi, yolcu memnuniyetini pozitif yönde anlamlı bir şekilde etkilemektedir.

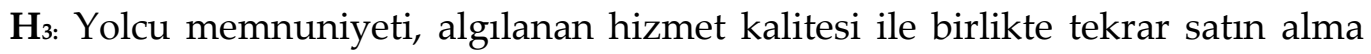
niyetini pozitif yönde anlamlı bir şekilde etkilemektedir.

$\mathbf{H}_{4:}$ Yolcu memnuniyeti, algilanan havayolu hizmet kalitesi ve tekrar satın alma niyeti arasında kısmi aracılık etkisi yapmaktadır.

\section{YÖNTEM}

Bu çalışmada bir hizmet sektörü olan havayolu yolcu taşımacılığında algılanan hizmet kalitesinin, müşteri memnuniyeti ve tekrar satın alma niyeti üzerindeki etkileri incelemek amaçlanmıştır. Hazırlanan anket formu ile Türkiye'deki havayolu şirketlerini iç hatlarda kullanan Türk yolcuların aldıkları hizmetleri, genel memnuniyet düzeylerini ve tekrar satın alma niyetleri belirtmeleri istenmiştir. Araştırmanın evrenini Türkiye'de Aralık 2012 - Nisan 2013 tarihlerinde havayollarını kullanan Türk yolcular oluşturmaktadır. Devlet Hava Meydanları İşletmesi verilerine göre belirtilen tarihlerde iç hatları kullanan yolcu sayısı yaklaşık 23,8 milyondur (Devlet Hava Meydanları İşletmesi, 2015). Tanımlanan evrendeki her elemanın, "eşit" ve "bağımsız" seçilme şansına sahip olması, araştırmanın güvenilirliği açısından oldukça önemlidir (Altunış1k ve diğerleri, 2010). Bu nedenle kolayda örnekleme yöntemi ile örneklem belirlenmiştir. Evrenin büyüklügü, zaman ve maliyet imkanlarının kısıtlı olması gibi nedenlerden dolayı, anket ulaşılabilen 500 yolcu ile yüz yüze yapılmıştır. Bunlardan veri sağlamaya elverişli 397 anket formu elde edilmiş, analize iç hatları kullanan yolcular dahil edildiğinden bu anketlerden, 311 adedi analize tabi tutulmuştur.

Anket formu hizmet kalitesi ölçeği ve demografik değişkenlerin bulunduğu iki bölümden oluşmaktadır. Ayrıca hizmet kalitesi ölçeğinin altına genel memnuniyet ve tekrar satın alma niyetini ölçmek amacıyla iki ifade eklenmiştir. Anket formu hazırlanırken daha önce yapılan yerli ve yabancı yazın incelenmiştir. İlgili çalışmalar Servqual'den faydalanarak hazırlanmış benzer ifadeler içermektedir. Bu çalışmalar arasında, SKYTRAX (havayolu değerlendirme sistemi) kriterleri ile ölçüşecek şekilde tasarlanan Değirmenci (2011)'nin anketindeki ifadeler kullanılmıştır. Anketin birinci kısmındaki performans ölçeği 5'li likert ölçeğine göre düzenlenmiştir (1=hiç 
katılmiyorum, 2=katılmiyorum, 3=ne katıliyorum ne katılmiyorum, 4=katıliyorum, $5=$ tamamen katıliyorum).

Elde edilen veriler istatistik paket programları kullanılarak analiz edilmiştir. Elde edilen verilerin analiz edilebilmesi için ilk önce verilerin normal dağılıp dağılmadığına bakılması gerekmektedir. Verilerin K-S testi ile birlikte basıklık ve çarpıklık değerlerine bakılarak parametrik testlere uygun olduğu görülmüştür.

Her araştırmanın olduğu gibi bu araştırmanın da bazı sınırlılıkları vardır. İlk olarak zamanın ve maddi imkanların kısıtlı olmasından dolayı bu araştırmada kullanılan örneklemin sınırlı olması bir kısıttır. Araştırmanın bir diğer kısıtı, havayolu işletmelerinden izin alınamadığından dolayı araştırmaya katılan yolcuları son 6 ay içerisinde havayolunu kullanan müşteriler olmasıdır.

\section{BULGULAR}

Katılımcıların demografik özelliklerine bakıldığında (Tablo 2) büyük çoğunluğunun (\%65) erkek katılımcılardan oluştuğu görülmektedir. Ayrıca katılımcıların \%46'sının 26-35 yaş aralığında olduğu, \%51'inin bekar olduğu, ve \%64'ünün önlisans veya lisans mezunu olduğu görülmektedir. Meslek değişkeni açısından kamu sektörü çalışanı katılımcılar ile özel sektör çalışanı katılımcıların eşit dağıldığg (\%27) görülmektedir. Katılımcıların \% 27'sinin 2001-3000 TL gelir düzeyinde olduğu bulunmuştur. Seyahat nedeni açısından iş nedenli seyahat eden katılımcların (\%44) ve tatil amaçlı seyahat eden katılımcıların (\%37) çoğunlukta olduğu görülmektedir (Tablo 2). 
Tablo 2. Katılımcıların Demografik ve Seyahat Değişkenleri

\begin{tabular}{|c|c|c|c|c|c|}
\hline Cinsiyet & Frekans & Yüzde & Meslek & Frekans & Yüzde \\
\hline Erkek & 204 & 65,6 & Kamu Çalışanı & 85 & 27,3 \\
\hline Kadin & 107 & 34,4 & Öğrenci & 46 & 14,8 \\
\hline \multicolumn{3}{|l|}{ Yaş } & Özel Sektör Çalışanı & 85 & 27,3 \\
\hline $18-25$ & 76 & 24,4 & İş Adamı/Yönetici & 47 & 15,1 \\
\hline $26-35$ & 143 & 46,0 & Diğer & 48 & 15,4 \\
\hline $36-45$ & 59 & 19,0 & \multicolumn{3}{|l|}{ Gelir Düzeyi } \\
\hline $46-55$ & 26 & 8,4 & 1000 TL ve altı & 45 & 14,5 \\
\hline 56 ve üstü & 7 & 2,3 & 1001-2000 TL & 68 & 21,9 \\
\hline \multicolumn{3}{|l|}{ Medeni Durum } & 2001-3000 TL & 86 & 27,7 \\
\hline Bekar & 161 & 51,8 & 3001-4000 TL & 51 & 16,4 \\
\hline $\begin{array}{l}\text { Evli } \\
\text { (Çocuksuz) }\end{array}$ & 39 & 12,5 & 4001 TL ve üstü & 61 & 19,6 \\
\hline Evli (Çocuklu) & 111 & 35,7 & & & \\
\hline \multicolumn{3}{|l|}{ Eğitim } & \multicolumn{3}{|l|}{ Seyahat Nedeni } \\
\hline İlköğretim & 4 & 1,3 & İş & 137 & 44,1 \\
\hline Lise & 22 & 7,1 & Tatil & 116 & 37,3 \\
\hline Önlisans/Lisans & 199 & 64,0 & Ziyaret & 18 & 5,8 \\
\hline Lisansüstü & 86 & 27,7 & Diğer & 40 & 12,9 \\
\hline
\end{tabular}

Havayolu işletmelerinde algılanan hizmet kalitesi ölçeğine yönelik açımlayıcı faktör analizi sonuçları Tablo 3'de verilmiştir. Öncelikli olarak verilerin açımlayıcı faktör analizi için uygunluğunu test etmek amacıyla yapılan Bartlett Küresellik testi ve KMO örneklem büyüklüğü testlerine bakılmıştır. Veriler Bartlett Küresellik testi sonucuna göre sig. $(p)=0,000$ düzeyinde anlaml, $\mathrm{KMO}$ testine $(0,835)$ göre ise yeterli örneklem büyüklügüne sahip olduğu bulunmuştur. Yapılan analiz sonucunda 11 ifade analiz dışı bırakılmıştır. Kalan ifadeler "çalışanlar", "online hizmetler", "empati", "temel hizmetler" ve "kabin hizmetleri" olmak üzere beş boyut altında toplanmıştır.

Yapılan analiz sonucunda çalışanlar boyutunda "çalışanların davranışları güven veriyor" $(0,833)$ ifadesi, online hizmetler boyutunda "web sitesi içeriği yeterlidir" $(0,925)$ ifadesi, empati boyutunda "yolculara özel ilgi gösterilir" $(0,697)$ ifadesi, temel hizmetler boyutunda "uçağın kalkışı ve varışı zamanındadır" $(0,826)$ ifadesi ve kabin hizmetleri boyutunda "Uçuş eğlence programları yeterlidir" $(0,792)$ ifadesi en yüksek faktör yüklerine sahip ifadelerdir.

Analiz sonucunda boyutlar toplam varyansın \%63'ünü açıklamaktadır. Yapılan güvenirlik analizi sonucunda algılanan havayolu hizmet kalitesi ölçeğinin Cronbach's Alpha katsayısı 0,864 bulunmuştur. Ayrıca, çalışanlar $(0,815)$, online hizmetler $(0,874)$, empati $(0,753)$, temel hizmetler $(0,728)$ ve kabin hizmetleri $(0,706)$ alt ölçeklerinin güvenirlik katsayıları hesaplanmıştır. Sonuçlara göre ölçeklerin oldukça güvenilir olduğu söylenebilir. 
Tablo 3. Algılanan Havayolu Hizmet Kalitesine Yönelik Faktör Analizi Sonuçları

\begin{tabular}{|c|c|c|c|c|}
\hline HAVAYOLU HİZMET KALİTESİ & $\begin{array}{l}\text { Faktör } \\
\text { Yükü }\end{array}$ & $\begin{array}{l}\text { Eigen } \\
\text { Değeri }\end{array}$ & $\begin{array}{c}\text { Açılanan } \\
\text { Varyans }\end{array}$ & $\begin{array}{c}\text { Cronbach } \\
\text { Alpha }\end{array}$ \\
\hline \multicolumn{5}{|l|}{ ÇALIŞANLAR $(\bar{x}=3,76)$} \\
\hline 1. Çalışanların davranışları güven veriyor & ,833 & \multirow{5}{*}{2,967} & \multirow{5}{*}{$\% 15,61$} & \multirow{5}{*}{0,815} \\
\hline 2. Çalışanlar nazik ve güler yüzlüdür & ,765 & & & \\
\hline 3. Çalışanların iş bilgisi yeterlidir & 724 & & & \\
\hline 16. Çalışanlar yardım etme isteği içerisindeler & ,618 & & & \\
\hline $\begin{array}{l}\text { 15. Beklenmedik durumlarda çalışanların } \\
\text { yaklaşımı olumludur }\end{array}$ &, 517 & & & \\
\hline \multicolumn{5}{|l|}{ ONLINE HIZZMETLER $(\overline{\mathrm{x}}=3,90)$} \\
\hline 12. Web sitesi içeriği yeterlidir & ,925 & \multirow{3}{*}{2,505} & \multirow{3}{*}{$\% 13,19$} & \multirow{3}{*}{0,874} \\
\hline 11. Web sitesinin kullanımı kolaydır & ,909 & & & \\
\hline 13. Online check-in işlemleri kolaydır & 764 & & & \\
\hline \multicolumn{5}{|l|}{ EMPATI $(\bar{x}=3,28)$} \\
\hline 28. Yolculara özel ilgi gösterilir & 697 & \multirow{4}{*}{2,430} & \multirow{4}{*}{$\% 12,79$} & \multirow{4}{*}{0,753} \\
\hline 27. Geciken yolculara yeterli tolerans gösterilir & 689 & & & \\
\hline 29. Çocuklu ailelere ve yaşlılara yardım edilir & 687 & & & \\
\hline $\begin{array}{l}\text { 30. Sorunlu bagaj işlemlerinde yapılan } \\
\text { işlemler yeterlidir }\end{array}$ & ,671 & & & \\
\hline \multicolumn{5}{|l|}{ TEMEL HİZMETLER $(\overline{\mathrm{x}}=3,43)$} \\
\hline 18. Uçağın kalkışı ve varışı zamanındadır & 826 & \multirow{4}{*}{2,189} & \multirow{4}{*}{$\% 11,52$} & \multirow{4}{*}{0,728} \\
\hline 23. Gecikmelerin ve iptallerin oluş sıklığı azdır & ,798 & & & \\
\hline 19. Transfer yolcularının taşınması yeterlidir &, 575 & & & \\
\hline 20. Verdiğim ücret beklentilerimi karşılar &, 549 & & & \\
\hline \multicolumn{5}{|l|}{ KABİN HİZMETLERI $(\overline{\mathrm{x}}=2,63)$} \\
\hline 7. Uçuş eğlence programları yeterlidir & ,792 & \multirow{3}{*}{2,040} & \multirow{3}{*}{$\% 10,74$} & \multirow{3}{*}{0,706} \\
\hline 8. Uçuş sırasında gazete ve dergiler yeterlidir & ,769 & & & \\
\hline 6. Yemekler lezzetli ve çeşitleri yeterlidir & ,684 & & & \\
\hline ÖLÇEK GENEL $(\overline{\mathrm{x}}=3,42)$ & & 12,131 & $\% 63,85$ & 0,864 \\
\hline KMO Örneklem Ölçüm Yeterliliği & \multicolumn{4}{|c|}{835} \\
\hline Bartlett Küresellik Testi Chi-Square & \multicolumn{4}{|c|}{2381,197} \\
\hline Anlamlılık Düzeyi & \multicolumn{4}{|c|}{,000 } \\
\hline
\end{tabular}

(1- Hiç Katılmıyorum...............5- Tamamen Katılıyorum)

Tablo 3'te görüldüğü gibi yolcuların genel olarak havayolu hizmet kalitesi algılarının ortalamanın üzerinde olduğu $(\bar{x}=3,42)$ görülmektedir. Alt boyutlarda en yüksek ortalamanın "online hizmetler" $(\bar{x}=3,90)$, "çalışanlar" $\quad(\bar{x}=3,76)$, "temel hizmetler" $(\bar{x}=3,43)$ ve "empati" $(\overline{x=3,28)}$ olduğu görülmektedir. "Kabin hizmetleri" boyutunda ise ortalamanın düşük olduğu $(\overline{x=2,63})$ görülmektedir.

Algılanan havayolu hizmet kalitesi ölçeğinin geçerliliğini test etmek amacıyla birinci ve ikinci seviye doğrulayıcı faktör analizi (DFA) yapılmıştır. DFA, gizil değişken analizi olarak bilinmekte ve kuramsal bir temeli olan nedensel modellerin sınanmasında kullanılmaktadır (Sümer, 2000: 49). Modellerin sınanmasında sıklıkla Ki- 
Kare Uyum testi $\left(\Delta \chi^{2}\right)$, yaklaşık hataların ortalama karekökü (RMSEA), standardize edilmiş kalıntıların karekökü (SRMR), uyum iyiliği indeksi (GFI), düzeltilmiş uyum iyiliği indeksi (AGFI), karşılaştırmalı uyum indeksi (CFI), fazlalık uyum indeksi (IFI) sık kullanılan ölçüt değerlerdir. Tablo 4 'te birinci ve ikinci seviye doğrulayıcı faktör analizi uyum iyiliği sonuçları ile birlikte ölçüt değerler verilmiştir.

Tablo 4. Doğrulayıcı Faktör Analizi Uyum İyiliği Sonuçları

\begin{tabular}{||c|c|c|c|c||}
\hline \hline & $\begin{array}{c}\text { 1. Seviye Faktör } \\
\text { Analizi }\end{array}$ & $\begin{array}{c}\text { 2. Seviye Faktör } \\
\text { Analizi }\end{array}$ & İyi Uyum & $\begin{array}{c}\text { Kabul Edilebilir } \\
\text { Uyum }\end{array}$ \\
\hline$\Delta \chi^{2}$ & $247,119^{*}$ & $260,753^{*}$ & $0 \leq \mathrm{x}^{2} \leq 2 \mathrm{df}$ & $0 \leq \mathrm{x}^{2} \leq 3 \mathrm{df}$ \\
\hline $\mathbf{d f}$ & 137 & 142 & - & - \\
\hline$\Delta \times \mathbf{2} / \mathbf{d f}$ & 1,804 & 1,836 & $0 \leq \mathrm{x}^{2} / \mathrm{df} \leq 2$ & $2 \leq \mathrm{x}^{2} / \mathrm{df} \leq 3$ \\
\hline RMSEA &, 051 &, 052 & $0 \leq \mathrm{RMSEA} \leq 0,05$ & $0 \leq \mathrm{RMSEA} \leq 0,08$ \\
\hline SRMR &, 047 &, 049 & $0 \leq \mathrm{SRMR} \leq 0,05$ & $0,05 \leq \mathrm{SRMR} \leq 0,10$ \\
\hline GFI &, 927 &, 923 & $0,95 \leq \mathrm{GFI} \leq 1,00$ & $0,90 \leq \mathrm{GFI} \leq 0,95$ \\
\hline AGFI &, 898 &, 897 & $0,90 \leq \mathrm{AGFI} \leq 1,00$ & $0,85 \leq \mathrm{GFI} \leq 0,90$ \\
\hline CFI &, 951 &, 947 & $0,97 \leq \mathrm{CFI} \leq 1,00$ & $0,95 \leq \mathrm{CFI} \leq 0,97$ \\
\hline IFI &, 952 &, 948 & $0,95 \leq \mathrm{IFI} \leq 1,00$ & $0,90 \leq \mathrm{IFI} \leq 0,95$ \\
\hline NFI &, 898 &, 892 & $0,95 \leq \mathrm{NFI} \leq 1,00$ & $0,90 \leq \mathrm{NFI} \leq 0,95$ \\
\hline
\end{tabular}

* p <0,01 Kaynak: Şimşek (2007: 46-48); Bayram, (2010: 70); Çelik ve Yılmaz (2013)

Modelin uyum iyiliği için Tablo 4'teki sonuçlara bakıldığında ki-kare uyum değerleri birinci seviye $(1,804)$ ve ikici seviye faktör analizi $(1,836)$ değerleri iyim uyum gösterdiği görülmektedir. RMSEA değeri ise 0.05 ile 0.08 arası bir değer alan modelin uyumu yeterlidir, 0.10 ve daha üstünde ise modelin uygunluğu zayıftır. SRMR değeri gözlenen kovaryans ile tahmin edilen kovaryans arasındaki standardize edilmiş farkı göstermektedir. Değerin sıfıra yakın olması mükemmel uyumu gösterirken 0,05'ten küçük olması iyi uyumu gösterir (Bayram, 2010). Tablo 4'teki RMSEA $(0,051 ; 0,052)$ ve SRMR $(0,047 ; 0,049)$ değerlerine bakıldığında doğrulayıcı faktör analizlerinin iyi uyum gösterdiği söylenebilir. GFI, AGFI, CFI ve IFI değerlerinin kabul edilebilir düzeyde olduğu görülürken, NFI $(0,898 ; 0,892)$ değerlerinin ise kabul edilebilir uyum değerine $(0,90)$ yakın olduğu görülmektedir. Birinci ve ikinci seviye faktör analizi regresyon katsayıları ve t değerleri Ek 1'deki tabloda verilmiştir.

Hipotezlerin testine ve aracılık etkisinin ölçülmesine yönelik olarak iki regresyon modeli kurulmuştur. Birinci modelde algilanan hizmet kalitesinin tekrar satın alma niyetine doğrudan etkisi ölçülmüştür. Analiz sonucunda hizmet kalitesinin tekrar satın alma niyetini $(\beta=0,539 ; \mathrm{t}=11,255 ; \mathrm{p}<0,001)$ pozitif yönde anlamlı olarak etkilediği tespit edilmiştir (Şekil 1A). Bu sonuç ile hipotez 1 kabul edilmiştir. İkinci regresyon modelinde ise algilanan hizmet kalitesinin, tekrar satın alma niyetine doğrudan ve yolcu memnuniyeti aracılığıyla etkisinin ölçümüne yönelik model kurulmuştur. Bu modelden elde edilen sonuçlara göre algilanan hizmet kalitesi, yolcu memnuniyetini $(\beta=0,605 ; \mathrm{t}=13,381 ; \mathrm{p}<0,001)$ pozitif yönde anlamlı olarak etkilediği tespit edilmiştir. Ortaya çıkan bu sonuç hipotez 2'yi desteklemektedir. Ayrıca, yolcu 
memnuniyeti, tekrar satın alma niyetini $(\beta=0,481 ; t=8,984 ; p<0,001)$ algılanan hizmet kalitesi etkisindeyken pozitif yönde anlamlı olarak etkilediği bulunmuştur. Bu sonuç hipotez 3'ü desteklemektedir (Şekil 1B).

Yolcu memnuniyetinin, algılanan hizmet kalitesi ve tekrar satın alma niyeti arasındaki kısmi aracılık etkisinin tespit edilebilmesi için nedensel adım (normal teori) ve bootstrap yöntemleri kullanılmıştır. Aracılık testlerinde kullanılan yöntemlerin avantaj ve dezavantajları (I. ve II. tip hata gibi) bulundu (Mallinckrodt vd. 2006) için iki yöntem birlikte kullanılmıştır. Nedensel adım yaklaşımında aracılık testinin yapılabilmesi için daha önce tespit edilen hipotez 1, 2 ve 3 etkilerinin varlığı şarttır. Diğer bir ifadeyle bağımsız değişken ile bağımlı değişken arasındaki etkinin (Şekil $1 \mathrm{~A}$ 'daki "c" yolu); bağımsız değişkenle aracı değişken arasındaki etkinin (Şekil 1B'deki "a" yolu) ve bağımsız değişken modelde bulunurken aracı değişkenle bağımlı değişken arasındaki etkinin (Şekil 1B'deki " $b$ " yolu) anlamlı olması gerekmektedir (Burmaoğlu vd. 2013). Bu yöntemde birinci modeldeki bağımsız değişken ile bağımlı değişken arasındaki doğrudan etkinin (Şekil 1A "c" yolu), aracı değişken eklenerek kurulan ikinci modeldeki etkiden (Şekil 1B " $\mathrm{c}^{\prime \prime}$ ” yolu) yüksek olması gerekmektedir. Bu yöntemde ikinci modeldeki bağımsız değişkenin bağımlı değişkene doğrudan etkisinin (c' yolu) anlamlı düzeyde çıkmasıyla kısmi aracılık etkisinin varlığı kabul edilmektedir. Eğer anlamlı bir etki tespit edilmezse tam aracılık etkisinin olduğu kabul edilir (Şimşek, 2007). Hesaplamalar standardize edilmemiş etki değerleri üzerinden yapılmaktadır. Modeldeki doğrudan etki şu şekilde hesaplanır: $c=a b+c^{\prime}$

Genellikle yürütülen çalışmalarda nedensel adım yöntemi kullanılmakta ve yöntemin sonucuna göre kısmi veya tam aracılık kararı verilmektedir. Sobel testi bu çalışmalarda rapor edilmemektedir. Ancak bilinmesi gereken önemli konu Sobel testinin aslında adımsal yöntemin son adımının istatistiksel olarak anlamlılığını kontrol ettiğidir (Iacobucci, 2008 aktaran: Burmaoğlu vd. 2013). Sobel testi ( $\mathrm{s}_{a}=$ "a" yolunun standart hatası ve $\mathrm{sb}_{\mathrm{b}}=$ "b" yolunun standart hatası olmak üzere) şu şekilde hesaplanir: $z=\frac{a b}{\sqrt{b^{2} s_{a}^{2}+a^{2} s_{b}^{2}+s_{b}^{2} s_{a}^{2}}}$ 


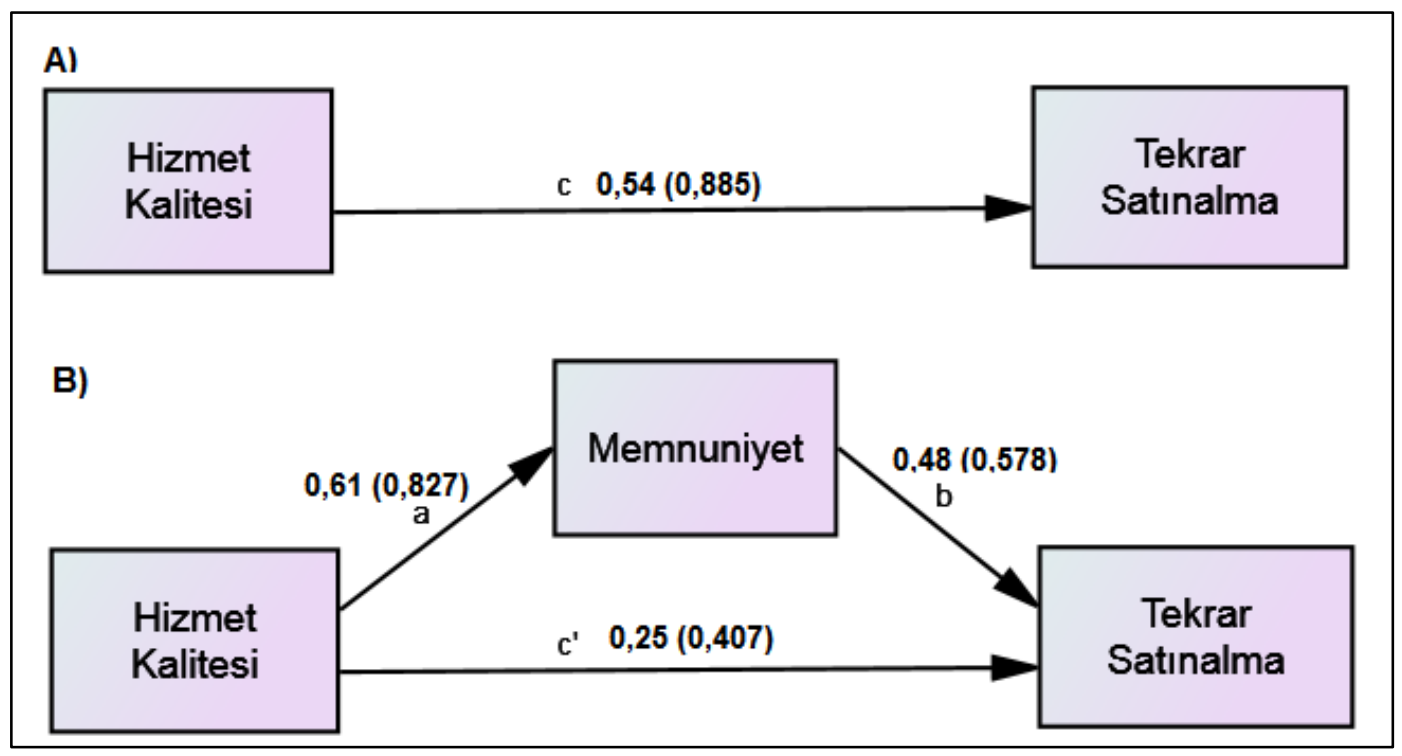

Şekil 1. Memnuniyetin, Hizmet Kalitesi ve Tekrar Satın alma Niyetine Kısmı Aracılık Etkisi

* Parantez içindeki rakamlar standardize edilmemiş etki katsayılarını göstermektedir.

Yapılan analizler sonucunda algilanan hizmet kalitesinin tekrar satın alma niyetine etkisinin doğrudan modelde (c yolu $\beta=0,885 ; \mathrm{t}=11,255$ ) yüksek düzeyde ve anlamlı bulunurken aracılık modelinde $\left(c^{\prime}\right.$ yolu $\left.\beta=0,407 ; t=4,624\right)$ orta düzeyde ve anlamlı bulunmuştur. Dolaylı etkinin $(\mathrm{aXb})$ anlamlılı̆̆ Sobel testi ile ölçülmüsştür. Test sonucunda yolcu memnuniyetinin, algilanan hizmet kalite ve tekrar satın alma niyeti ilişkisinde aracılık etkisinin $(\mathrm{z}=7,478 ; \mathrm{p}<0,001)$ anlamlı olduğu tespit edilmiştir.

Aracılık etkisini test etmek amacıyla diğer yöntem olarak bootstrap tekniği kullanılmıştır. Bu yöntemde yeniden örnekleme yapılarak, standart sapma ve güven aralığı gibi istatistikler ve parametrik olmayan tahminleme problemlerinde kullanılan basit ve güvenilir bir yöntemdir. Bir istatistik hesaplanmasında $N$ gözlemden oluşan bir veri setinin 1/N olasılıkla yeniden oluşturulması ve bu işlem istenildiği kadar tekrar edildiğinde $\mathrm{B}$ adet birbirinden farklı veri seti elde edilir ve istatistikler bu veri seti kullanılarak hesaplanır (Burmaoğlu vd. 2013). Veri setinden rastgele seçilen 200 durum alınmıştır. Yüzde 95 güvenirlikte 2000 bootstrap örneklemi oluşturulmuştur. Yapılan analiz sonucunda aracı modelde algilanan hizmet kalitesinin yolcu memnuniyetine etkisi $(\beta=0,784)$, yolcu memnuniyetinin tekrar satın alma niyetine etkisi $(\beta=0,549)$ ve algilanan hizmet kalitesinin tekrar satın alma niyetine doğrudan $(\beta=0,455)$ ve dolaylı etkisi $(\beta=0,431)$ pozitif yönlü ve 0,001 düzeyinde anlamlı olarak tespit edilmiştir (Tablo 5). Bu sonuçlar, nedensel adım yöntemiyle benzer şekilde, yolcu memnuniyetinin, algılanan hizmet kalitesi ve tekrar satın alma niyeti ilişkisinde kısmı aracılık etkisini desteklemektedir. Dolayısıyla hipotez 4 doğrulanmıştır. 
Tablo 5. Aracilık Analizi Sonuçları

\begin{tabular}{||l|c|c|c|c|c|c||}
\hline \multirow{2}{*}{ Yol (Etki) } & \multicolumn{2}{|c|}{$\begin{array}{c}\text { Regresyon } \\
\text { Değerleri }\end{array}$} & \multicolumn{4}{c||}{$\begin{array}{c}\text { \%95 Güven Aralı̆̆ında } \\
\text { Bootstrap (with bias correction) }\end{array}$} \\
\cline { 2 - 7 } & $\beta$ & SH & $\beta$ & SH & Alt Sinır & Üst Sınır \\
\hline c (HK --> TSN) & $0,885^{*}$ & 0,079 & - & - & - & - \\
\hline a (HK --> MEM) & $0,827^{*}$ & 0,062 & $0,784^{*}$ & 0,097 & 0,580 & 0,969 \\
\hline b (MEM --> TSN) & $0,578^{*}$ & 0,064 & $0,549^{*}$ & 0,089 & 0,375 & 0,727 \\
\hline c' (HK --> TSN) & $0,407^{*}$ & 0,088 & $0,455^{*}$ & 0,110 & 0,219 & 0,646 \\
\hline AXb & $0,478^{* *}$ & 0,064 & $0,431^{*}$ & 0,100 & 0,260 & 0,649 \\
\hline * p<0,01 **(Sobel testi Z değeri $=7,478 ; S H=0,064 ; p=0,001)$ \\
\hline
\end{tabular}

Not: Tahminler HK=Hizmet Kalitesi; MEM=Memnuniyet; TSN=Tekrar Satın alma Niyeti)

\section{SONUÇ}

Hizmet kalitesi ve dolayısıyla müşteri memnuniyeti müşterilerin işletmelerde tutulması için ve bu müşterilerin davranışsal sadakatleri yani tekrar satın alma yapmaları işletmelerin yoğun rekabet ortamında ayakta kalabilmeleri için oldukça önemlidir. Çünkü mevcut müşterilerin işletmede tutulması, işletmeye yeni müşteriler çekilmesinden daha az maliyetlidir. Bu çalışmada havayollarında hizmet kalitesini oluşturan boyutlar ortaya konmaya çalışılmıştır. Yapılan analizler sonucunda, "çalışanlar", "online hizmetler", "empati", "temel hizmetler" ve "kabin hizmetleri" olmak 5 boyut bulunmuştur. Bu sonuç daha önceki yapılan bazı çalışmalar ile benzerlik göstermektedir (Chang ve Yeh, 2002; Okumuş ve Asil, 2007; Kalthom vd., 2012; Pekkaya ve Akıllı, 2013). Araştırma, farklı sayıda hizmet kalitesi boyutu bununan diğer çalışmalar ile ayrışmaktadır (Robledo, 2001; Gilbert ve Wong, 2003; Chen ve Chang, 2005; Saha ve Theingi, 2009; Çelikkol vd. 2012). Bu boyutlardan "çalışanlar", "online hizmetler", "empati" ve "temel hizmetler" boyutlarının araştırmaya katılan yolcular tarafından yüksek kalitede algılandığı bulunurken "kabin hizmetleri" boyutunun düşük kalitede algılandığı tespit edilmiştir.

Çalışmadan elde edilen diğer bir sonuç ise müşteri memnuniyetinin, hizmet kalitesi ve tekrar satın alma niyeti arasında kısmi aracılık etkisi bulunduğudur. Diğer bir ifadeyle hizmet kalitesinin, müşteri memnuniyetine ve yarı dolaylı olarak tekrar satın alma niyetine pozitif yönlü etki ettiği görülmektedir. Buradan yola çıkarak, havayolu işletmelerinin mevcut hizmet kalitelerini arttırmaları, özellikle düşük kalitede algılanan "kabin hizmetleri"ne yönelik iyileştirmeler yapmaları hem müşteri memnuniyetini hem de mevcut müşterilerin tekrar satın alma niyetini arttıracaktır. Bu açıdan düşünüldüğünde araştırma, havayolu işletmelerine katkı sağlamaktadır.

Bulunan kısmi aracılık etkisi nedeniyle çıkarılabilecek diğer bir sonuç ise, modele müşteri memnuniyeti değişkenin eklenmesi ile hizmet kalitesinin, tekrar satın alma niyetine doğrudan etkisinin yok olmadığıdır. Özellikle Türkçe alanyazında bazı yazarlar tarafından, hemen hemen eş değer olarak görülen hizmet kalitesi ve müşteri memnuniyeti kavramlarının sanılanın aksine birbirlerinin yerine kullanılamayacağ 
görülmektedir. Yine alanyazında var olan müşteri değeri, his yumağı, müşteriler arası karşılaştırmalar ve durumsal faktörler gibi kavramların müşteri memnuniyetini belirleyen faktörler olduğu söylenebilir. Bu açıdan bakıldı̆̆ında bu çalışmanın yeni çalışmalara 1şık tutacağı düşünülmektedir. İleride yapılacak çalışmalarda memnuniyeti etkileyen diğer faktörlerin modele eklenerek, daha ayrıntılı analiz edilmesi uygun olacaktır.

Yapılan araştırmalarda, havayolu işletmelerinde farklı hizmet kalitesi boyutları bulunmuştur. Bu araştırmada, Türkiye'de yapılan Okumuş ve Asil (2007)'in çalışmalarını destekleyerek, beş boyut elde edilmiş ve doğrulayıcı faktör analizi yöntemi ile bu sonuç desteklenmiştir. Bu açıdan bakıldığında araştırma ölçeğin Türkiye özelinde kullanılabilir olduğunu ve beş boyuttan oluştuğunu geçerlemiştir. Bundan sonraki çalışmalarda, belirlenen havayolu hizmet kalitesi boyutlarının kullanımı araştırmacılara önerilebilir. Ayrıca, ileride yapılacak çalışmalarda daha geniş zamanda, daha yüksek örneklem sayısına ulaşılması halinde örneklemin evreni temsil yeteneği artırılabilir. Bununla birlikte, havayolu işletmelerinden gerekli izinler sağlanabilir ise müşterilerin hizmeti alınmasından hemen sonra hizmet kalitesi değerlendirilmesi sağlanabilir. Böylece, bazı kısıtlar ortadan kaldırılarak, araştırmada daha doğru veriler elde edilmiş olacaktır.

\section{KAYNAKÇA}

Altunışık, R., Coşkun, R., Bayraktaroğlu, S. ve Yıldırım, E. (2010). Sosyal bilimlerde araştırma yöntemleri: SPSS uygulamalı. Sakarya yayıncılık.

Ataman, G., Behram Kartaltepe, N. ve Eşgi, S. (2011). Measuring the service quality in business air travel market by using servqual model and a research on 'business class' passengers of Turkish airlines, Selçuk Üniversitesi Sosyal Bilimler Enstitüsü Dergisi, 26, 73-87.

Bayram, N. (2010). Yapısal eşitlik modellemesine giriş Amos uygulamaları. Ezgi Kitabevi.

Burmaoğlu, S., Polat, M. ve Meydan, C. H. (2013). Örgütsel davranış alanında ilişkisel analiz yöntemleri ve Türkçe yazında aracılık modeli kullanımı üzerine bir inceleme. Anadolu Üniversitesi Sosyal Bilimler Dergisi, 13 (1), 13-26.

Chang, Y. H. ve Yeh, C. H. (2002). A survey analysis of service quality for domestic airlines, European Journal of Operational Research, 139, 166-177.

Chen, C. F. (2008). Investigating structural relationships between service quality, perceived value, satisfaction, and behavioral intentions for air passengers: Evidence from Taiwan, Transportation Research Part A, 42, 709-717.

Chen, F. Y. ve Chang, Y. H. (2005). Examining airline service quality from a process perspective, Journal of Air Transport Management, 11, 79-87.

Çelik, H. E. ve Yılmaz, V. (2013). Lisrel 9.1 ile Yapısal Eşitlik Modellemesi: Temel Kavramlar Uygulamalar-Programlama (Yenilenmiş 2. Baskı). Ankara: Anı Yayıncılık.

Çelikkol, E. S., Uçkun, C. G., Tekin, V. N. ve Çelikkol Ş. (2012). A research on factors that have effect on satisfaction and preferences of customers with regard to airline transport within domestic flights in Turkey, İşletme Araştırma Dergisi, 4 (3), 70-81. 
Devlet Hava Meydanları İşletmesi, Erişim Adresi: http://www.dhmi.gov.tr/istatistik.aspx Erişim Tarihi: 26.05.2015

Dwyer, L., Forsyth, P. ve Spurr, R. (2004), Evaluating tourism's economic effects: new and old approaches, Tourism management, 25, 307-317.

Frost, F. A. ve Kumar M. (2001). Service quality between internal customers and internal suppliers in an international airline. İnternational Journal of Quality\&Reliability Management, 18 (4), 371-386.

Gilbert, D. ve Wong, R. K.C. (2003). Passenger expectations and airline services: a Hong Kong based study, Tourism Management, 24, 519-532.

Giritlioğlu, İ. (2012). Yiyecek içecek bölümlerinde işgörenlerin ve müşterilerin hizmet kalitesi beklenti ve algıları: Termal otellerde bir araştırma, Balıkesir Üniversitesi Sosyal Bilimler Enstitüsü, Yayımlanmamış Doktora Tezi, Balıkesir.

Global Report on Aviation, World tourism organization Publishing, Erişim Adresi: http://affiliatemembers.unwto.org/publication/global-report-adventure-tourism, Erişim Tarihi: 01.05.2015.

Hui, T. K. ve Wan T. W. D. (2003). Singapore's image as a tourist destination, International journal of tourism research, 5, 305-313.

Kalthom, A., Jan, M. T. ve Noor Hazilah, A. M. (2012). A structural equation modelling approach to validate the dimensions of servperf in airline industry of Malaysia, International journal of engineering and management sciences, 3 (2), 134-141.

Lorenzoni, N. ve Lewis, B. R. (2004). Service recovery in the airline industry: a cross-cultural comparison of the attitudes and behaviours of British and Italian front-line personnel, Managing service quality 14 (1), 11-25.

Lu, J. L., Ling, F. I. (2008). Cross-cultural perspectives regarding service quality and satisfaction in Chinese cross-strait airlines, Journal of Air Transport Management, 14, 16-19.

Mahajan, V. C. ve Rau, S.S. (2009). An empirical study on service quality perceptions of domestic airline consumers in India, International Journal on Information Sciencesand Computing, 3 (2), 69-74.

Nadiri, H., Hussain, K., Ekiz, E. H. ve Erdoğan, Ş. (2008). An investigation on the factors influencing passengers' loyalty in the North Cyprus national airline, The TQM Journal, 20 (39), 265-280.

Oh, H., Fiore, A. M. ve Jeoung, M. (2015). Measuring experience economy concepts: Tourism applications, Journal of travel research, 46, 119-132.

Okumuş, A. ve Asil, H. (2007). Havayolu taşımacılığında yerli ve yabancı yolcuların memnuniyet düzeylerine göre beklentilerinin incelenmesi, Kocaeli Üniversitesi Sosyal Bilimler Enstitüsü Dergisi, 13, 152-175.

Park, J. W. (2007). Passenger perceptions of service quality: Korean and Australian case studies, Journal of Air Transport Management, 13, 238-242.

Park, J. W., Robertson, R. ve Wu, C. L. (2004). The effect of airline service quality on passengers' behavioural intentions: a Korean case study, Journal of Air Transport Management, 10, 435-439. 
Pekkaya, M. ve Akıllı, F. (2013). Statistical analysis and evaluation of airline service quality by servperf-servqual scale, Ekonomik ve Sosyal Araştırmalar Dergisi, 9 (1), 75-96.

Robledo, M. A. (2001). Measuring and managing service quality: integrating customer expectations, Managing Service Quality, 11 (1), 22-31.

Saha, G. C. ve Theingi. (2009). Service quality, satisfaction, and behavioural intentions A study of low-cost airline carriers in Thailand, Managing Service Quality, 19 (39), 350-372.

Sultan, F. ve Simpson, M. C. (2000). International service variants: airline passenger expectations and perceptions of service quality, Journal of services marketing, 14 (3), 188-216.

Suziki, Y., Tyworth, J. E. ve Novack, R. A. (2001). Airline market share and customer service quality: a reference-dependent model, Transportation research part A, 35, 773-788.

Şimşek, Ö. F. (2007). Yapısal eşitlik modellemesine giriş: Temel ilkeler ve LISREL uygulamaları. Ankara: Ekinoks Yayıncılık.

Tsaur Sheng-Hshiung, Chang Te-Yi, Yen Chang-Hua., (2002), The evaluation of airline service quality by fuzzy MCDM, Tourism Management, 23, 107-115.

WTO, World Tourism Organisation Tourism Highlights 2014, Erişim Adresi: http://mkt.unwto.org/publication/unwto-tourism-highlights-2014-edition, Erişim Tarihi: 01.04.2014

Yildız, O. ve Erdil T. S. (2013). Comparative measuring of service quality in the passenger carriage of Turkish Airlines industry, Marmara Üniversitesi Öneri Dergisi, 10 (39), 89100 . 
EK 1. Algılanan Hizmet Kalitesi Doğrulayıcı Faktör Analizi Sonuçları

\begin{tabular}{|c|c|c|c|c|c|c|}
\hline \multirow{2}{*}{$\underset{8}{\stackrel{1}{9}}$} & \multicolumn{3}{|c|}{ Birinci Seviye Faktör Analizi } & \multicolumn{3}{|c|}{ İkinci Seviye Faktör Analizi } \\
\hline & $\beta$ (Düzeltilmiş) & SH & t değeri & $\beta$ (Düzeltilmiş) & SH & t değeri \\
\hline \multicolumn{4}{|c|}{ Çalışanlar } & \multicolumn{3}{|c|}{$(\beta=0,868 ; t=8,460)$} \\
\hline S16 & 0,702 & \multicolumn{2}{|c|}{ Sabit } & 0,704 & \multicolumn{2}{|c|}{ Sabit } \\
\hline S15 & 0,684 & 0,086 & 11,449 & 0,691 & 0,087 & 11,478 \\
\hline S1 & 0,690 & 0,082 & 9,664 & 0,685 & 0,083 & 9,429 \\
\hline S3 & 0,632 & 0,085 & 9,106 & 0,631 & 0,086 & 8,942 \\
\hline $\mathbf{S 2}$ & 0,596 & 0,083 & 8,687 & 0,588 & 0,084 & 8,47 \\
\hline \multicolumn{4}{|c|}{ Temel Hizmetler } & \multicolumn{3}{|c|}{$(\beta=0,749 ; t=7,683)$} \\
\hline S19 & 0,677 & 0,098 & 8,588 & 0,670 & 0,098 & 8,484 \\
\hline $\mathbf{S 2 0}$ & 0,668 & \multicolumn{2}{|c|}{ Sabit } & 0,669 & \multicolumn{2}{|c|}{ Sabit } \\
\hline S18 & 0,542 & 0,11 & 7,367 & 0,550 & 0,111 & 7,409 \\
\hline $\mathbf{S 2 3}$ & 0,495 & 0,097 & 6,818 & 0,500 & 0,098 & 6,828 \\
\hline \multicolumn{4}{|c|}{ Online Hizmetler } & \multicolumn{3}{|c|}{$(\beta=0,466 ; t=5,886)$} \\
\hline S13 & 0,867 & \multicolumn{2}{|c|}{ Sabit } & 0,833 & \multicolumn{2}{|c|}{ Sabit } \\
\hline S12 & 0,734 & 0,12 & 7,025 & 0,764 & 0,134 & 6,775 \\
\hline S11 & 0,669 & 0,12 & 6,763 & 0,694 & 0,134 & 6,532 \\
\hline \multicolumn{4}{|c|}{ Empati } & \multicolumn{3}{|c|}{$(\beta=0,864 ; \mathrm{t}=$ Sabit $)$} \\
\hline $\mathbf{S 2 8}$ & 0,813 & \multicolumn{2}{|c|}{ Sabit } & 0,805 & \multicolumn{2}{|c|}{ Sabit } \\
\hline S30 & 0,675 & 0,071 & 11,211 & 0,677 & 0,072 & 11,158 \\
\hline S29 & 0,582 & 0,059 & 9,634 & 0,585 & 0,06 & 9,63 \\
\hline $\mathbf{S 2 7}$ & 0,563 & 0,075 & 9,311 & 0,569 & 0,076 & 9,346 \\
\hline \multicolumn{4}{|c|}{ Kabin Hizmetleri } & \multicolumn{3}{|c|}{$(\beta=0,527 ; \mathrm{t}=6,479)$} \\
\hline S8 & 0,795 & \multicolumn{2}{|c|}{ Sabit } & 0,789 & \multicolumn{2}{|c|}{ Sabit } \\
\hline S7 & 0,670 & 0,089 & 8,383 & 0,673 & 0,094 & 8,097 \\
\hline S9 & 0,495 & 0,091 & 7,024 & 0,499 & 0,093 & 6,941 \\
\hline
\end{tabular}

* Bütün regresyon katsayıları $\mathrm{p}<0,001$ düzeyinde anlamlı bulunmuştur. 